\title{
REVIEW ARTIKEL: APOPTOSIS PADA KANKER PAYUDARA
}

\author{
Article Review On Apoptosis In Breast Cancer \\ Adryan Fristiohady*, Ikra Agustina \\ Jurusan Farmasi, Fakultas Farmasi, Universitas Halu Oleo, Kampus Hijau Bumi Tridharma, \\ Anduonohu, Kec. Kambu, Kota Kendari, Sulawesi Tenggara 93232, Indonesia \\ *Koresponden Email : adryanfristiohady@uho.ac.id
}

DOI: https://doi.org/10.32382/mf.v16i2.1561

\begin{abstract}
Breast cancer is a type of cancer that forms in the cells of the breast, which is common in women. According to the American Cancer Society, about 41,760 women and 500 men died in 2019. The Data from the World Health Organization (2020) shows that breast cancer is the most cases in Indonesia, with a total of 58,256 out of 384,809 cases, and its prevention is one of the most important function of apoptosis. This review aims to provide an insight into apoptosis, stages, and genes that play the role and mechanisms in breast cancer. The method used is a literature study, both from primary and secondary literature and the searches was carried out using online-based library search tool such as NCBI-PubMed, Google Scholar, and Elsevier. The data obtained was classified according to the framework, while the data on the relationship between apoptosis and breast cancer and the journal writing were carried out using the given format. Inadequate apoptosis is one of the mechanisms underlying tumor development. There are two signaling pathways in apoptosis such as extrinsic and intrinsic pathway. Furthermore, caspase plays a role on the extrinsic pathway, and members of the Bcl-2 family plays a role on the intrinsic pathway. Bcl2 are antiapoptotic and pro-apoptotic molecule. Bcl-2 anti-apoptotic are able to work with pro-proliferative signal to support breast cancer initiation and development. Furthermore, Bcl-2 pro-apoptosis support the apoptosis process, therefore it is able to remove excess or damaged cells.
\end{abstract}

Key words: Apoptosis, breast cancer, Bcl-2, Caspase.

\begin{abstract}
ABSTRAK
Kanker payudara adalah kanker yang paling sering terjadi pada wanita. Menurut American Cancer Society, sekitar 41.760 wanita dan 500 pria diperkirakan meninggal akibat kanker payudara pada 2019. Data World Health Organization (2020) menunjukkan kasus kanker yang paling banyak terjadi di Indonesia adalah kanker payudara yakni 58.256 dari total 384.809 kasus kanker. Pencegahan kanker adalah salah satu fungsi utama apoptosis. Review jurnal ini bertujuan untuk menyediakan pandangan yang berkaitan dengan apoptosis, tahapan, gen yang berperan serta mekanismenya pada kanker payudara. Metode yang digunakan yaitu metode studi pustaka, baik yang berasal dari pustaka primer maupun sekunder. Penelusuran pustaka dilakukan menggunakan instrument pencarian pustaka berbasis online seperti NCBI-PubMed, Google Scholar, dan Elsevier. Data yang diperoleh kemudian disusun sesuai kerangka, data hubungan apoptosis dengan kanker payudara dan penulisan review jurnal dilakukan sesuai format yang diberikan. Ketidakcukupan apoptosis menjadi salah satu mekanisme yang mendasari perkembangan tumor. Terdapat dua jalur pensinyalan pada apoptosis; jalur ekstrinsik dan jalur intrinsik. Caspase berperan pada jalur ekstrinsik, dan anggota keluarga Bcl-2 berperan pada jalur intrinsik. Bcl2 dapat berupa molekul antiapoptosis dan pro-apoptosis. Bcl-2 anti-apoptosis dapat bekerja sama dengan sinyal pro-proliferatif untuk mendukung inisiasi dan perkembangan kanker payudara. Bcl-2 pro-apoptosis dapat mendukung proses apoptosis sehingga dapat menghilangkan sel-sel berlebih atau sel-sel yang rusak.
\end{abstract}

Kata kunci : Apoptosis, Kanker payudara, Bcl-2, Caspase.

\section{PENDAHULUAN}

Kanker merupakan suatu penyakit yang disebabkan oleh pertumbuhan dan proliferasi sel yang tidak terkontrol (Nabila dan Indrayudha, 2019). Kanker payudara adalah penyakit heterogen ( $\underline{\mathrm{He} d k k ., 2019})$. Kanker ini menjadi 
salah satu tumor ganas wanita yang paling umum terjadi (Yan dkk., 2018) dan penyebab utama kematian bagi wanita di seluruh dunia (Vergara dkk., 2020). Sekitar 41.760 wanita dan 500 pria diperkirakan meninggal akibat kanker payudara pada 2019 (American Cancer Society, 2019). Berdasarkan data World Health Organization (WHO) juga menunjukkan kasus kanker yang paling banyak terjadi di Indonesia adalah kanker payudara yakni 58.256 dari total 384.809 kasus kanker.

$\begin{array}{llrr}\text { Apoptosis sangat penting untuk } & \text { payudara normal dan } \\ \text { perkembangan } & \text { nonal }\end{array}$ homeostasis (Williams dan Cook, 2015). Apoptosis berguna bagi tubuh untuk menghilangkan sel-sel berlebih, rusak atau berbahaya (Park dkk., 2014). Pencegahan kanker adalah salah satu fungsi utama apoptosis (Pfeffer dan Singh, 2018). Namun, sel-sel kanker menghindari apoptosis, sehingga memungkinkan proliferasi berlebihan. Oleh karena itu, induksi apoptosis dianggap sebagai strategi penting untuk pencegahan dan terapi kanker (Xie dkk., 2015). Sel-sel kanker menghindari apoptosis dengan ekspresi berlebih atau menstabilkan protein keluarga Bcl-2 antiapoptotik dan secara transkripsi atau post-transkripsi menghambat anggota keluarga Bcl-2 proapoptotik. (Matsuura dkk., 2016). Selain itu, ada berbagai jalur biokimia selama apoptosis yang akhirnya bertemu dan menghasilkan aktivasi keluarga sistein protease yang disebut caspase (Jamalzadeh dkk., 2017). Review jurnal ini bertujuan untuk menyediakan pandangan yang berkaitan dengan apoptosis, tahapan, gen yang berperan serta mekanismenya pada kanker payudara.

\section{METODE}

Data yang digunakan dalam penulisan jurnal ini dikumpulkan menggunakan metode studi pustaka, baik yang berasal dari pustaka primer maupun sekunder. Penelusuran pustaka dilakukan menggunakan instrument pencarian pustaka berbasis online seperti NCBI-PubMed, Google Scholar, dan Elsevier. Kata kunci yang digunakan untuk penelusuran pustaka terkait dengan "breast cancer", "apoptosis breast cancer", "Bcl-2" dan "caspase". Pustaka yang sudah didapat kemudian disusun sesuai kerangka, data hubungan apoptosis dengan kanker payudara dan penulisan review jurnal dilakukan sesuai format yang diberikan.

\section{HASIL DAN PEMBAHASAN}

Apoptosis adalah kematian sel terprogram (Basu dkk., 2018). Apoptosis merupakan proses biologis yang menghilangkan kerusakan, kelebihan, atau infeksi sel melalui mekanisme yang dikontrol secara genetik. Proses ini memainkan peran penting peran dalam pengembangan organisme, imunitas, dan homeostasis jaringan; dan perubahan dalam apoptosis berkontribusi pada penyakit manusia termasuk kanker dan autoimun (Luna-Vargas dan Chipuk, 2016). Kematian sel biasanya melibatkan dua mekanisme yaitu kematian sel terprogram (apoptosis) dan nekrosis (Jan dan Chaundry, 2019). Mekanisme yang tepat dari kematian sel akibat nekrosis atau kematian yang diinduksi secara eksternal dalam sel kanker tidak diketahui (Basu dkk., 2018).

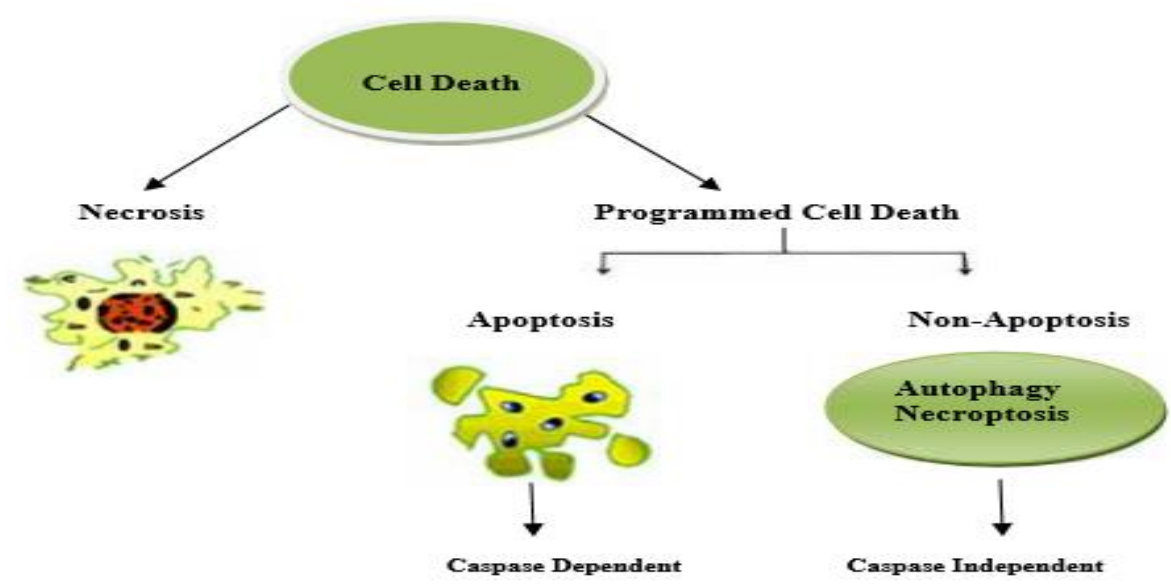

Gambar 1. Mode umum kematian sel kanker (Jan dan Chaundry, 2019).

Kematian sel terprogram atau apoptosis berbeda dengan nekrosis sel karena memiliki karakteristik morfologi yang berbeda (Jan dan
Chaundry, 2019). Kematian sel kanker dapat dilihat pada Gambar 1. Kematian sel kanker melibatkan dua mekanisme, yaitu kematian sel 
terprogram dan nekrosis. Kematian sel terprogram terutama kematian sel dasar apoptosis dan non-apoptosis. Kematian sel akibat apoptosis adalah kematian sel terprogram. Kematian sel akibat non-apoptosis adalah autophagy dan necroptosis. Kematian sel autophagy disebut sebagai kematian sel tipe II. Kematian sel autophaghy adalah proses degradasi diri dan berperan penting dalam degradasi komponen seluler di dalam sel yang rusak dalam vakuola autofagik. Necroptosis adalah bentuk kematian nekrotik yang terprogram, dan dihasilkan oleh sinyal kematian yang sama yang menginduksi apoptosis. Nekrosis merupakan proses acak dan tidak terkontrol yang biasanya diakibatkan oleh rangsangan tertentu seperti trauma toksik atau kerusakan fisik. Nekrosis secara morfologis ditandai oleh pembengkakan sitoplasma dan organel (retikulum endoplasma dan mitokondria), gangguan plasma (Jan dan Chaundry, 2019).

Pada jaringan payudara, mekanisme seluler untuk apoptosis diatur oleh jalur apoptosis intrinsik, yang terdiri dari keluarga protein Bcl-2 (Williams dan Cook, 2015). Apoptosis dapat dipicu oleh dua mekanisme utama, yaitu pengikatan ligan kematian pada reseptor kematian di jalur ekstrinsik atau sitotoksisitas yang memulai jalur intrinsik (mitokondria). Secara keseluruhan, jalur ini bertemu untuk mengaktifkan serangkaian protease spesifik sistein aspartil (caspase), yang membelah protein seluler kunci dan memecah sel (Koff dkk., 2015). Ketidakcukupan apoptosis menjadi salah satu mekanisme yang mendasari perkembangan tumor (Ibrahim dkk., 2014). Oleh karena itu, sinyal pro-apoptosis dan antiapoptosis diatur dengan ketat dalam sel-sel epitel payudara normal (Williams dan Cook, 2015).

\section{Tahapan Apoptosis}

Tahapan apoptosis secara garis besar terbagi menjadi empat tahap:

1. Tahap pertama yaitu tahap penginduksi apoptosis. Adanya sinyal kematian sel sebagai penginduksi apoptosis, dapat bersifat fisiologis seperti hormon dan sitokin, biologis berupa virus, bakteri, parasit, kimia berupa obat, atau fisik akibat adanya radiasi dan toksin (Sari, 2018).

2. Tahap kedua adalah tahap integrasi atau pengaturan yaitu transduksi signal, dan induksi gen terkait apoptosis (Sari, 2018).

3. Tahap ketiga adalah tahap pelaksanaan apoptosis, dimana terjadi perubahan morfologi dan kimia seperti degradasi DNA, pembongkaran sel, pembentukan badan apoptotik (Sari, 2018).

4. Tahap keempat adalah tahap fagositosis atau eliminasi oleh makrofag, dendritik atau sel yang berdekatan dengan sel apoptosis. Peristiwa apoptosis melibatkan adanya pemadatan inti sel, pemadatan dan pembagian sitoplasma ke dalam selaput ikat badan apoptotis, dan kerusakan kromosom ke dalam fragmen yang berisi berbagai nukleosom (Sari, 2018). Pada tahap akhir apoptosis, beberapa fitur morfologis termasuk blebbing membran (rusaknya sitoskeleton sel sehingga membran menjadi mennonjol keluar), modifikasi ultrastruktural dari organel sitoplasma dan hilangnya integritas membran (Pistritto dkk., 2016).

\section{Mekanisme Apoptosis}

Apoptosis mempunyai mekanisme yang sangat kompleks dan rumit (Sari, 2018). Kematian sel akibat apoptosis biasanya ditandai dengan kondensasi bahan kromatin, fragmentasi DNA terjadi pada nukleus, penyusutan sel, dinamis blebbing membran, dan hilangnya adhesi ekstraseluler matriks. Selanjutnya terjadi perubahan biokimia seperti eksternalisasi fosfatidilserin, dan aktivasi dari sistein aspartil protease, yang disebut caspase yang menyebabkan kematian sel (Jan dan Chaundry, 2019). Sasaran caspase termasuk ratusan protein vital, seperti protein sitoskeletal, kinase, dan faktor transkripsi (Matsuura dkk., 2016). Dua jalur pensinyalan pada apoptosis yaitu jalur intrinsik atau mitokondria dan jalur reseptor ekstrinsik atau kematian (Sisinni dkk., 2019). 


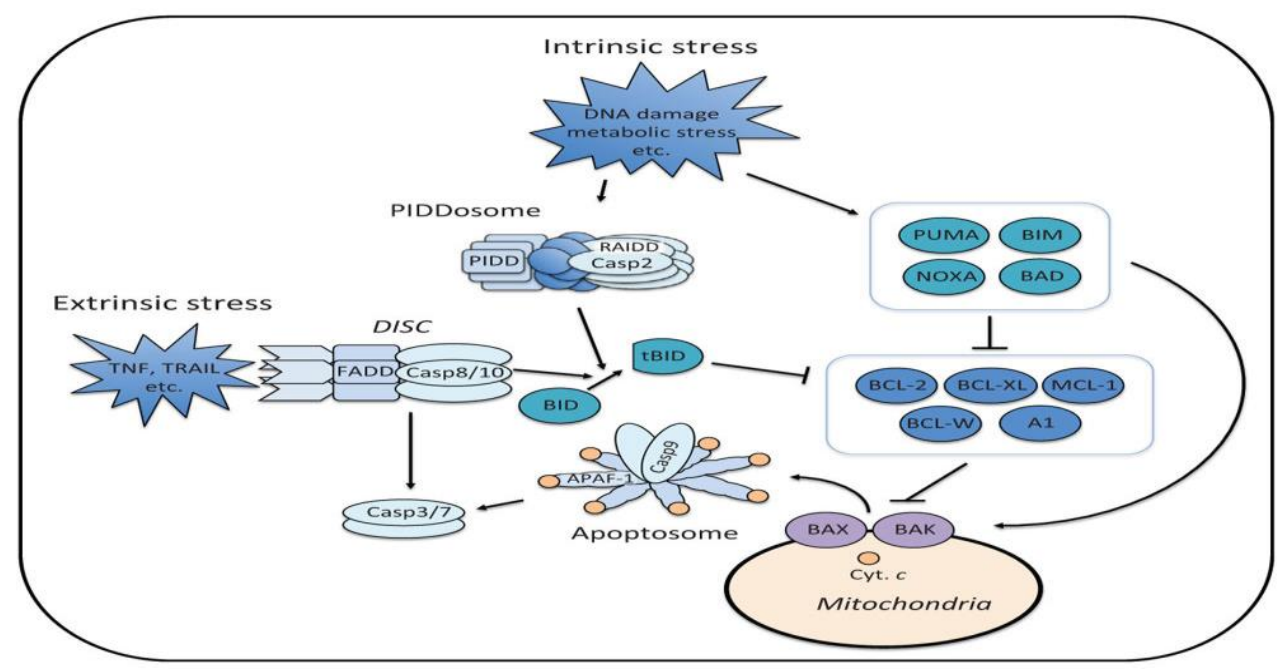

Gambar 2. Jalur Apoptosis (Matsuura dkk., 2016).

Dua mekanisme pensinyalan molekuler yang berbeda pada apoptosis yaitu jalur reseptor kematian (ekstrinsik) dan jalur mitokondria (intrinsik). Stres intrinsik (seperti kerusakan DNA dan stres metabolik) menginduksi ekspresi dan/ atau aktivasi protein proapoptotik hanya domain $\mathrm{BH} 3$ (BH3 only), yang menekan protein keluarga Bcl-2 antiapoptotik atau mengaktifkan BAX (Bcl-2-Associated $x$ protein) dan BAK (Bcl-2 Antagonist Killer 1) secara langsung. BAX dan BAK menginduksi mitochondrial outer membrane permeabilization atau permeabilisasi membran luar mitokondria (MOMP). Setelah MOMP, sitokrom c dilepaskan dari ruang antarmembran mitokondria. Pelepasan sitokrom c memicu pembentukan apoptosom di sitoplasma, dan mengaktifkan caspase-9. Caspase-9 memotong dan mengaktifkan caspase efektor, caspase-3 dan caspase-7. Stres intrinsik juga melibatkan pembentukan PIDDsome yang terdiri dari PIDD (p53 with a Death Domain), RAIDD (RIP Associated ICHI/CED Gomologus Protein with Death Domain), dan caspase-2. Melalui aktivasi yang diinduksi oleh kedekatan, casapse-2 menjadi aktif dan memotong BID. Setelah dibelah, BID (tBID: BID terpotong) menjadi protein BH3 aktif saja. Stres ekstrinsik (mis., TNF dan TRAIL) dimediasi melalui reseptor kematian, yang membentuk DISC (Death Inducing Signaling Complex) dengan FADD (Fas Associated with Death Domain) dan caspase-8. Caspase-8 memotong dan mengaktifkan caspase efektor atau memicu jalur apoptosis intrinsik melalui pembelahan BID. TNF (Faktor Nekrosis Tumor) dan TRAIL (TNFRelated Apoptosis Iducing Ligan) adalah ligan yang menginduksi apoptosis terkait TNF. Jalur apoptosis ini ditunjukkan pada Gambar 2.

\section{Jalur ekstrinsik}

Jalur ekstrinsik disebut sebagai jalur reseptor kematian (Kim dkk., 2014). Apoptosis jalur ekstrinsik dimulai dari adanya pelepasan molekul sinyal disebut ligan oleh sel lain dan bukan berasal dari sel yang akan mengalami apoptosis (Sari, 2018). Pensinyalan apoptosis melalui jalur ekstrinsik terlibat ketika ligan ekstraseluler seperti TNF (Tumor Necrosis Factor), Fas-L (Fas Ligand), dan TRAIL (TNFRelated Apoptosis-Inducing Ligand) domain ekstraseluler dari DR (Death Receptors), yaitu reseptor TNF tipe 1 atau Tumor Necrosis Factor Receptor-1 (TNFR1), Fas (disebut CD95/Apo-1) dan reseptor TRAIL. Beberapa caspase prodomain melibatkan Death Efektor Domain atau domain efektor (DED), dan Caspase Activation and Recutment Domain atau domain rekrutmen caspase (CARD) yang berinteraksi dengan protein lain dan terhubung dengan jalur pensinyalan. DED melibatkan caspase-8 dan caspase-10 sedangkan CARD melibatkan caspase-1, caspase-2, caspase-4, caspase-5, caspase-9, caspase-11 dan caspase-12 (Jan dan Chaundry, 2019).

Beberapa sel tidak mati sebagai respons terhadap jalur ekstrinsik saja dan memerlukan langkah amplifikasi yang diinduksi oleh caspase- 8 . Kemudian capase- 8 menargetkan Bid protein $\mathrm{BH} 3$ (BH3-interacting-domain death agonist) untuk pembelahan dan menghasilkan fragmen t-Bid (truncated Bid) yang diaktifkan. Kemudian t-Bid mengaktifkan protein multidomain proapoptotik untuk menginduksi permeabilitas membran luar mitokondria (MOMP), sehingga melibatkan jalur intrinsik (Pistritto dkk., 2016). 


\section{Jalur intrinsik}

Jalur apoptosis intrinsik dimediasi oleh sinyal intraseluler pada mitokondria dalam menanggapi kondisi stres yang berbeda (Pistritto dkk., 2016). Mitokondria memainkan peran kunci dalam proses apoptosis (Looi dkk., 2013). Jalur intrinsik dipicu oleh berbagai tekanan ekstraseluler dan intraseluler seperti stres oksidatif, iradiasi, dan pengobatan dengan obat sitotoksik (Jan dan Chaundry, 2019). Anggota keluarga Bcl-2 mmemiliki peran penting dalam jalur mitokondria (Gao dkk., 2017). Bcl-2 dan Bcl-xL adalah protein anti-apoptosis yang mencegah pelepasan sitokrom c. Sitokrom c bergabung dengan Apaf-1 (Apoptotic protease activating factor-1) dan pro-caspase-9 untuk menghasilkan apoptosome. Apoptosome adalah kompleks multi-protein yang terdiri dari kompleks berbentuk cincin sevenspoke, yang memicu caspase-9 diikuti dengan aktivasi pensinyalan caspase-3 yang mengarah pada pemecahan sel dan berakhir dengan apoptosis (Jan dan Chaundry, 2019).

Protein yang umumnya terlibat dalam jalur intrinsik termasuk SMAC/DIABLO (Second Mitochondrial Activator of Caspases/Direct IAP binding protein with low $P I)$, Caspase-9 (Cysteinyl aspartic acidprotease9), Bcl-2 (B-cell lymphoma protein 2), Bcl-w (Bcl2 like protein), Nox (Phorbol-12-myristate13-acetateinduced protein 1), Aven (Cell death regulator Aven) dan Myc (Jan dan Chaundry, 2019). Sitokrom c berikatan dengan sitosolik
Apaf-1 (Apoptosis protease activating factor-1) dan memicu pembentukan kompleks (apoptosome) yang menginduksi inisiator procaspase-9 ke domain caspase (CARD), memungkinkan autoaktivasi dan kemudian proteolisis. Proses ini mengaktifkan caspase-3, caspase-6 dan caspase-7 untuk membelah substrat seluler yang mengarah pada kematian sel apoptosis (Pistritto dkk., 2016).

\section{Jalur apoptosis pada kanker payudara}

Perkembangan kanker terdiri dari banyak langkah yang terjadi secara progresif dimulai dengan mutasi sel, ke tumorigenesis, hingga metastasis. Selama perkembangannya, sel-sel kanker juga menghadapi program seluler untuk menghilangkan sel-sel yang rusak atau abnormal atau disebut apoptosis (Fernald dan Kurokawa, 2013). Ketidakcukupan apoptosis menjadi salah satu mekanisme yang mendasari perkembangan tumor (Ibrahim dkk., 2014). Pada kanker payudara manusia, hingga 80\% dari kasus kanker payudara triple negatif yang diperkuat myelocytomatosis (MYC) atau proto-oncogene (TNBC) memperkuat coamplifikasi MCL1. Ekspresi Bcl-2 sering berkorelasi dengan tingkat ekspresi Estrogen Receptor (ER) pada kanker payudara $\mathrm{ER}^{+}$. Penelitian oleh Williams dan Cook (2014) menunjukkan bahwa protein Bcl-2 anti-apoptosis dapat bekerja sama dengan sinyal pro-proliferatif untuk mendukung inisiasi dan perkembangan kanker payudara.

Tabel 1. Misregulasi transgenik protein keluarga Bcl-2 pada model tikus untuk pengembangan mammae dan tumorigenesis payudara (Williams dan Cook, 2015).

\begin{tabular}{|c|c|c|c|c|}
\hline Kelas & Faktor Bcl-2 & $\begin{array}{c}\text { Model Rekayasa } \\
\text { Genetik }\end{array}$ & $\begin{array}{c}\text { Perkembangan } \\
\text { Fenotip }\end{array}$ & $\begin{array}{c}\text { Fenotip Kanker } \\
\text { Payudara }\end{array}$ \\
\hline \multirow[t]{5}{*}{ Effector } & Bak & tak dapat diterapkan & tak dapat diterapkan & $\begin{array}{ll}\text { tak } & \text { dapat } \\
\text { diterapkan } & \\
\end{array}$ \\
\hline & \multirow[t]{4}{*}{$\operatorname{Bax}$} & WAP-Bax & $\begin{array}{l}\text { Merusak } \\
\text { pertumbuhan MEC } \\
\text { alveolar; apoptosis / } \\
\text { involusi premature }\end{array}$ & $\begin{array}{ll}\text { tak } & \text { dapat } \\
\text { diterapkan } & \end{array}$ \\
\hline & & MMTV-Myc X Bax+/- & tak dapat diterapkan & $\begin{array}{l}\text { Perubahan } \\
\text { multiplisitas } \\
\text { tumor }\end{array}$ \\
\hline & & Bax-/- & Involusi normal & $\begin{array}{l}\text { Sangat tidak } \\
\text { tumorgrnik }\end{array}$ \\
\hline & & C3(1)-TAg X Bak+/- & tak dapat diterapkan & $\begin{array}{l}\text { Mengurangi } \\
\text { apoptosis pada } \\
\text { tahap } \\
\text { preneoplastik }\end{array}$ \\
\hline \multirow[t]{2}{*}{ Activator } & Bim & Bim-/- & $\begin{array}{l}\text { TEB / pengisian } \\
\text { lumen }\end{array}$ & $\begin{array}{l}\text { tak dapat } \\
\text { diterapkan }\end{array}$ \\
\hline & $\begin{array}{l}\text { Bid } \\
\text { Puma }\end{array}$ & tak dapat diterapkan & tak dapat diterapkan & $\begin{array}{l}\text { tak dapat } \\
\text { diterapkan }\end{array}$ \\
\hline
\end{tabular}




\begin{tabular}{|c|c|c|c|c|}
\hline Sensitizer & $\begin{array}{l}\text { Bad } \\
\text { Bik } \\
\text { Noxa }\end{array}$ & tak dapat diterapkan & tak dapat diterapkan & $\begin{array}{l}\text { tak dapat } \\
\text { diterapkan }\end{array}$ \\
\hline \multirow[t]{4}{*}{$\begin{array}{l}\text { Anti- } \\
\text { apoptotic }\end{array}$} & \multirow[t]{2}{*}{ Bcl-2 } & WAP-Bcl2 & $\begin{array}{l}\text { Mengurangi } \\
\text { apoptosis pada } \\
\text { TEBs, mengisi } \\
\text { lumen selama masa } \\
\text { pubertas; } \\
\text { mengurangi } \\
\text { kematian sel selama } \\
\text { involusi }\end{array}$ & $\begin{array}{l}\text { Percepatan } \\
\text { tumorigenesis } \\
\text { mammae yang } \\
\text { diinduksi } \\
\text { MMTV-Myc, } \\
\text { pembentukan } \\
\text { tumor payudara } \\
\text { yang diinduksi } \\
\text { karsinogen } \\
\text { tertunda }\end{array}$ \\
\hline & & WAP-TAg;WAP-Bcl2 & tak dapat diterapkan & $\begin{array}{l}\text { Mengurangi } \\
\text { latensi tumor }\end{array}$ \\
\hline & Bcl-xL & $\begin{array}{l}\text { WAP-Cre X Bcl- } x L^{f l f l} \\
\text { MMTV-Cre X Bcl- } \\
x L^{f l f l}\end{array}$ & $\begin{array}{l}\text { Penurunan apoptosis } \\
\text { selama involusi }\end{array}$ & $\begin{array}{l}\text { tak dapat } \\
\text { diterapkan }\end{array}$ \\
\hline & $\begin{array}{l}\text { A1 } \\
\text { Bcl-w } \\
\text { Mcl-1 }\end{array}$ & tak dapat diterapkan & tak dapat diterapkan & $\begin{array}{l}\text { tak dapat } \\
\text { diterapkan }\end{array}$ \\
\hline
\end{tabular}

Apoptosis pada kanker dimulai dengan aktivasi jalur reseptor kematian oleh FAS, TRAIL atau TNF $\alpha$ mengarah pada dua mekanisme pensinyalan. Ligan TRAIL atau FAS mendorong interaksi reseptor FAS dengan FADD dan caspase- 8 untuk membentuk kompleks DISC. Jalur apoptosis pada kanker dapat dilihat pada Gambar 3. TNF $\alpha$ menginduksi sementara Tumor Necrosis Factor receptor-1 atau reseptor faktor nekrosis tumor-1 (TNFR1) dengan TNFR-Associated Death Domain proteins atau protein adaptor (TRADD), TNFRAssociated Factor- 2 atau faktor 2 terkait reseptor TNF (TRAF2), TNFR-Associated Factor-5 atau faktor 5 terkait reseptor TNF (TRAF5), Celullar Inhibitor of Apoptosis Protein atau inhibitor seluler dari protein apoptosis $1 / 2$ (cIAP1/2) dan Receptor-Interecting Protein atau reseptor yang berinteraksi dengan reseptor (RIP), dan membentuk kompleks pensinyalan I. Kompleks I memicu sejumlah sinyal hilir, seperti Nuclear factor kappa $B$ (NF-kB), c-JUN N-terminal Kinase (JNK) dan p38 untuk meningkatkan kelangsungan hidup dengan menginduksi ekspresi gen antiapoptotik (seperti cFLIP) penghambat umum pensinyalan TNFR. Namun, modifikasi posttranslasional kompleks I, seperti deubiquitination RIP, dapat mempromosikan disosiasi RIP1 dan TRADD dari kompleks; mengikat FADD dan caspase-8 atau caspase-10 untuk membentuk kompleks II apoptosis. Pembentukan DISC atau kompleks 2 memunculkan dua mekanisme yang menyebabkan kematian sel: induksi langsung efektor caspase-3 dan caspase-7 dalam sel tipe I dan pembelahan Bid (tBID), yang melibatkan jalur apoptosis intrinsik. Dalam jalur ini, rangsangan, seperti kerusakan DNA atau adanya tBID, menyebabkan BAX dan BAKk berinteraksi dan menginduksi permeabilitas membran luar mitokondria (MOMP). Peningkatan yang dihasilkan dalam MOMP menyebabkan pelepasan sitokrom c dan Smac (Second mitochondria-derived activator of caspase) ke dalam sitoplasma. Sitokrom c menginduksi APAF1 dan caspase-9 untuk mempromosikan caspase-9 auto-aktivasi dan aktivasi berikutnya dari caspase efektor. Smac berinteraksi dengan xIAP untuk mencegah penghambatan caspase-9 dan caspase-3 (Koff dkk., 2015). 


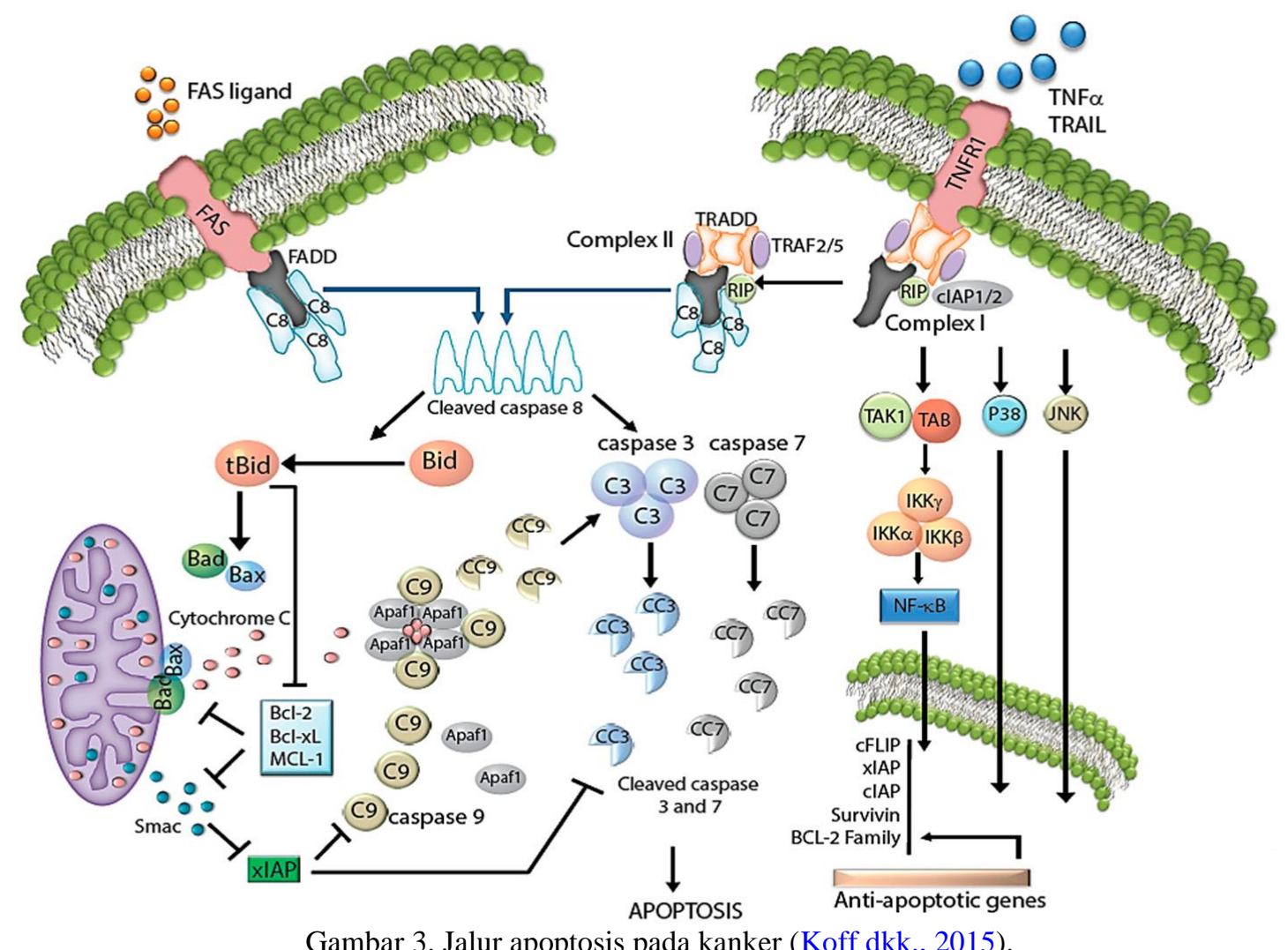

Gen yang Berpengaruh pada Apoptosis

Apoptosis secara morfologis ditandai dengan blebbing membran, kondensasi kromatin, dan fragmentasi DNA. Jalur apoptosis adalah proses perantara yang menghubungkan berbagai sinyal stres dengan eksekusi kematian sel yang dimediasi caspase (Matsuura dkk., 2016). Berikut gen-gen yang berpengaruh pada apoptosis secara garis besar terbagi atas dua keluarga besar (caspase dan $\mathrm{Bcl}-2$ ).

\section{Caspase (cysteine aspartate-specific proteases)}

Caspase yang terlibat dalam apoptosis dapat dikelompokkan berdasarkan mekanisme kerjanya sebagai inisiator (caspase-8 dan -9) atau caspase efektor berupa caspase-3, caspase-6, dan caspase-7 (Alotaibi1 dkk., 2017). Caspase apoptosis inisiator memiliki prodomain $\mathrm{N}$ - terminal besar yang berinteraksi dengan protein adaptor spesifik yang diperlukan untuk aktivasi yang disebabkan oleh dimerisasi. Dimerisasi caspase inisiator terjadi dalam kompleks protein spesifik (mis., PIDD osome untuk caspase-2, DISC untuk caspase-8, dan apoptosome untuk caspase-9). Setelah diaktifkan, inisiator caspase membelah caspases efektor. Tanpa prodomain besar, caspase efektor tidak memerlukan protein adaptor untuk aktivasi yang disebabkan oleh dimerisasi. Sebaliknya, caspase efektor dimerisasi secara spontan hanya diaktifkan pada saat pembelahan antara subunit kecil dan besar oleh caspase inisiator aktif. Caspase efektor yang diaktifkan kemudian membelah sejumlah substrat protein untuk memulai apoptosis (Matsuura dkk., 2016). 


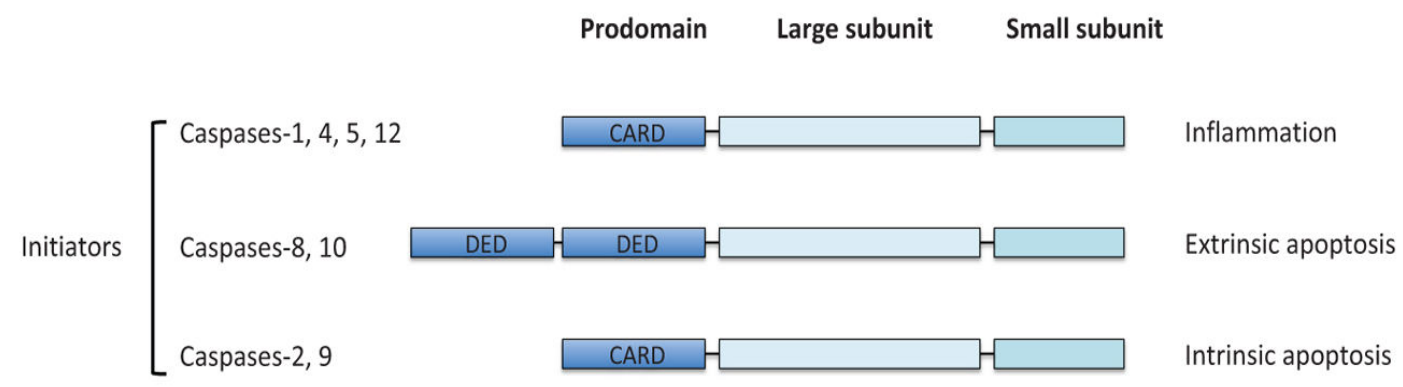

Effectors Caspases-3, 6, 7

Gambar 4. Struktur caspase (Matsuura dkk., 2016)

Semua caspase memiliki subunit besar dan subunit kecil, yang sangat diperlukan untuk aktivitas protease. Struktur caspase ditunjukkan pada Gambar 4. Caspase dapat dibagi menjadi dua jenis: inisiator dan efektor. Sementara caspase efektor (caspase-3, caspase-6, dan caspase-7) memiliki prodomain pendek, inisiator memiliki prodomain panjang yang memainkan peran penting untuk aktivasi yang diinduksi oleh jarak yang dimediasi oleh interaksi dengan protein adaptor. Caspase-1, caspase-4, caspase5 , dan caspase-12 terlibat dalam peradangan, sedangkan caspase-8/caspase-10 dan caspase2/caspase-9 masing-masing memulai jalur apoptosis ekstrinsik dan intrinsik.

\section{Bcl-2 (B-cell lymphoma 2)}

Bcl-2 adalah pengatur utama kematian sel atau kelangsungan hidup sel, berupa molekul antiapoptosis dan proapoptosis. Proses utama apoptosis dikontrol oleh protein kelompok Bcl2(Arianingrum dkk., 2016). Bcl-2 pro-apopteosis adalah regulator utama dari apoptosis (Wang dan Zeng, 2018). Bcl-2 anti-apoptosis yaitu Bcl2-A1, Bcl-2, Bcl-xL, Bcl-w dan Mcl-1 dan proapoptosis diantaranya BAD, BAK, BAX, BID, BIK, BIM, NOXA, Hrk dan PUMA (Williams dan Cook, 2015).

\section{Antiapoptotic $\mathrm{BCL}-2$ family proteins}

Proapoptotic multidomain $\mathrm{BCL}-2$ family proteins

\section{Proapoptotic BH3-only proteins}

$B C L-2, B C L-W, B C L-X L, M C L-1, A 1$

\begin{tabular}{|l|l|l|l|l|l|l|l|}
\hline BH4 & BH3 & BH1 & BH2 & TM \\
\hline
\end{tabular}

Gambar 5. Regulasi protein keluarga Bcl-2 (Matsuura dkk., 2016).

Protein keluarga Bcl-2 dibagi menjadi tiga kelompok, yaitu protein anti-apoptotik, multidomain pro-apoptotik, dan pro-apoptotok. Protein anti-apoptotik Bcl-2 berupa Bcl-2 (B-cell lymphoma 2), Bcl-W (BCL-2-like 2 protein), $\mathrm{Bcl}-\mathrm{xL}$ (BCL-2-related protein long isoform), MCL-1 (myeloid cell leukemia 1), dan A1/BFL1 (BCL-2-related gene A1). Protein multidomain proapoptotik berupa BAX (BCL-2-associated $x$ protein), BAK (BCL-2 antagonist killer 1), dan BOK (BCL-2-related ovarian killer). Protein proapoptotik berupa BIM (BCL-2-interacting mediator of cell death), PUMA (p53upregulated modulator of apoptosis), BID (BCL2-interacting domain death agonist), $\mathrm{BAD}$
(BCL-2 antagonist of cell death), dan NOXA/PMAIP1 (Phorbol-12-myristate-13acetate-induced protein 1). Protein keluarga BCL-2 ditunjukkan pada Gambar 5.

BCL-2 dan BCL-xL berinteraksi dengan semua protein BH3 kecuali untuk NOXA, sementara MCL-1 dapat mengikat semua protein $\mathrm{BH} 3$ kecuali untuk BAD. Berdasarkan catatan, BIM, PUMA, dan BID mampu berinteraksi dengan semua protein keluarga BCL-2 antiapoptotik. Selanjutnya, BIM, PUMA, dan BID mengaktifkan BAX dan BAK dalam model aktivator-derepressor langsung (Matsuura dkk., 2016). Harakiri (Hrk) adalah pengatur kematian sel yang secara fisik 
berinteraksi dengan protein penekan kematian Bcl2 dan BclX (L), dan membentuk kompleks tidak aktif dari Bcl2-Hrk dan/atau BclX (L)-Hrk (Tvrdik dkk., 2012). Bcl-2 dan Bcl-xL bertindak sebagai inhibitor apoptosis dalam sel (Looi dkk., 2013; Alotaibi dkk., 2017).

Protein famili Bcl-2 dapat menghambat atau menginduksi pengeluaran sitokrom-c ke dalam sitosol yang akan mengaktivasi Caspase 9 dan Caspase 3, menghasilkan proses apoptosis. Kadar protein Bcl-2 yang tinggi akan menghindarkan/menjaga sel-sel dari kematian awal sel oleh apoptosis. Bcl-2 sering terekspresi berlebihan pada berbagai keganasan meskipun tanpa adanya translokasi kromosom yang mengakibatkan perubahan gen Bcl-2. Antiapoptosis $\mathrm{Bcl}-2$ akan menghalangi proses tersebut melalui jalur inhibisi Bax dan atau Bak. Protein Bcl-2 akan menekan proses apoptosis dengan cara mencegah aktivasi Caspase yang akan menghasilkan proses tersebut (Muhartono dan Subekti, 2017).

Bcl-2 pro-apoptosis melalui aktivasi Bak dan atau Bax akan membentuk mitochondrial apoptosis-induced channel (MAC) dan melakukan mediasi keluarnya sitokrom-c, sehingga terjadi apoptosis pada sel (Muhartono dan Subekti, 2017). Oleh karena itu, interaksi kompleks antara $\mathrm{Bcl}-2$ proapoptosis dan antiapoptosis dapat mengintegrasikan informasi pensinyalan untuk mengatur kematian sel (Williams dan Cook, 2015).

\section{KESIMPULAN}

Apoptosis berperan penting dalam menghilangkan sel-sel yang rusak atau abnormal. Ketidakcukupan apoptosis menjadi salah satu mekanisme yang mendasari perkembangan tumor. Sel-sel kanker menghindari apoptosis sehingga memicu proliferasi berlebihan. Terdapat dua jalur pensinyalan pada apoptosis; jalur ekstrinsik dan jalur intrinsik. Caspase berperan pada jalur ekstrinsik, dan anggota keluarga Bcl-2 berperan pada jalur intrinsik. Caspase yang terlibat dalam apoptosis dapat dikelompokkan berdasarkan mekanisme kerjanya sebagai inisiator dan efektor. Bcl2 dapat berupa molekul antiapoptosis dan pro-apoptosis. Bcl-2 anti-apoptosis dapat bekerja sama dengan sinyal pro-proliferatif untuk mendukung inisiasi dan perkembangan kanker payudara. Bcl-2 proapoptosis dapat mendukung proses apoptosis sehingga dapat menghilangkan sel-sel berlebih atau sel-sel yang rusak.

\section{SARAN}

Mekanisme apoptosis dan implikasinya untuk tujuan pengobatan penyakit terutama pada kanker payudara sebaiknya terus diteliti. Apoptosis merupakan fenomena yang masih terus diteliti karena memegang peranan penting dalam homeostasis sel dalam tubuh serta dapat mengatasi penyakit, termasuk pada kanker payudara.

\section{DAFTAR PUSTAKA}

Alotaibi, M.R., Hassan, Z.K., Al-Rejaie, S.S., Alshammari, M.A., Almutairi, M.M., Alhoshani, A.R., Alanazi, W.A., Hafez, M.M., \& Al-Shabanah, O.A. 2018. Characterization of apoptosis in a breast cancer cell line after IL-10 silencing. Asian Pacific journal of cancer prevention: APJCP, 19(3), 777.

American Cancer Society. 2019. Breast Cancer Basic Facts \& Figures 2019-2020. American Cancer Society: Atlanta.

Arianingrum, R. 2016. The Effect Of p-Hidroxy m-Methoxy Chalcone (pHmMK) ON $\mathrm{Bcl}-2$ and Bax Protein Expression In MCF-7 Breast Cancer Cell Lines. Jurnal Penelitian Saintek, 21(1), $10-20$

Basu, S.C., Boyle, P., Ma, R., Agarwal, A., Basu, M., Moskal, J.R., Banerjee, S., \& Tuteja, N. 2018. Induction of Apoptosis in Metastatic Breast Cancer Cells: XV. Downregulation of DNA Polymerase$\alpha$-Helicase Complex (Replisomes) and Glyco-Genes. In Biochemical and Biophysical Roles of Cell Surface Molecules (pp. 199-221). Springer, Singapore.

Fernald, K., \& Kurokawa, M. 2013. Evading apoptosis in cancer. Trends in cell biology, 23(12), 620-633.

Luna-Vargas, M.P., \& Chipuk, J.E. 2016. The deadly landscape of pro-apoptotic BCL2 proteins in the outer mitochondrial membrane. The FEBS journal, 283(14), 2676-2689.

Gao, S., Li, X., Ding, X., Qi, W., \& Yang, Q. 2017. Cepharanthine induces autophagy, apoptosis and cell cycle arrest in breast cancer cells. Cellular Physiology and Biochemistry, 41(4), 1633-1648.

He, X., Xue, M., Jiang, S., Li, W., Yu, J., \& Xiang, S. 2019. Fucoidan promotes apoptosis and inhibits emt of breast cancer cells. Biological and Pharmaceutical Bulletin,42(3), 442- 
447.

Ibrahim, M.A., Elbakry, R.H., \& Bayomy, N.A. 2016. Effect of bisphenol A on morphology, apoptosis and proliferation in the resting mammary gland of the adult albino rat. International journal of experimental pathology, 97(1), 27-36.

Jamalzadeh, L., Ghafoori, H., Aghamaali, M., \& Sariri, R. 2017. Induction of apoptosis in human breast cancer MCF-7 cells by a semi-synthetic derivative of artemisinin: a caspase-related mechanism. Iranian journal of biotechnology, 15(3), 157.

Jan, R., \& Chaundhry, G.,S. 2019. Understanding apoptosis and apoptotic pathways targeted cancer therapeutics. Advanced pharmaceutical bulletin, 9(2), 205.

Kim, E.A., Jang, J.H., Lee, Y.H., Sung, E.G., Song, I.H., Kim, J.Y., Kim., S., Sohn, H.Y., \& Lee, T.J. 2014. Dioscin induces caspase-independent apoptosis through activation of apoptosis-inducing factor in breast cancer cells. Apoptosis, 19(7), 1165-1175.

Koff, J.L., Ramachandiran, S., \& BernalMizrachi, L. 2015. A time to kill: targeting apoptosis in cancer. International journal of molecular sciences, 16(2), 2942-2955.

Looi, C. Y., Arya, A., Cheah, F.K., Muharram, B., Leong, K.H., Mohamad, K., Wong, W.F., Rai, N., \& Mustafa, M.R. 2013. Induction of apoptosis in human breast cancer cells via caspase pathway by vernodalin isolated from Centratherum anthelminticum (L.) seeds. PloS one, $8(2)$.

Matsuura, K., Canfield, K., Feng, W., \& Kurokawa, M. 2016. Metabolic regulation of apoptosis in cancer. In International review of cell and molecular biology (Vol. 327, pp. 4387). Academic Press.

Muhartono, M., \& Subeki, S. 2017. Aktivitas Antikanker Senyawa Brusein-A terhadap Ekspresi Bax pada Tikus yang Diinduksi Dimetilbenz $(\alpha)$ antrasen. Jurnal Kedokteran Universitas Lampung, 1(3), 469-472.

Nabilla, I. I., \& Indrayudha, P. 2019. Aktivitas Sitotoksik Ekstrak Etanol, Fraksi
Etanol, Etil-Asetat, dan Heksana Kulit Jeruk Purut (Citrus hystrix DC.) terhadap Sel Kanker Payudara T47D. Pharmacon: Jurnal Farmasi Indonesia, 16(1), 11-17.

Park, S.E., Shin, W.T., Park, C., Hong, S.H., Kim, G.Y., Kim, S.O., Ryu, C.H., Hong, S.H., \& Choi, Y.H. 2014. Induction of apoptosis in MDA-MB231 human breast carcinoma cells with an ethanol extract of Cyperus rotundus L. by activating caspases. Oncology reports, 32(6), 2461-2470.

Pfeffer, C.M., \& Singh, A.T. 2018. Apoptosis: a target for anticancer therapy. International journal of molecular sciences, 19(2), 448.

Pistritto, G., Trisciuoglio, D., Ceci, C., Garufi, A., \& D'Orazi, G. 2016. Apoptosis as anticancer mechanism: function and dysfunction of its modulators and targeted therapeutic strategies. Aging (Albany NY), 8(4), 603.

Sari, L. M. 2018. Apoptosis: Mekanisme molekuler kematian sel. Cakradonya Dental Journal, 10(2), 65-70.

Sisinni, L., Pietrafesa, M., Lepore, S., Maddalena, F., Condelli, V., Esposito, F., \& Landriscina, M. 2019. Endoplasmic reticulum stress and unfolded protein response in breast cancer: The balance between apoptosis and autophagy and its role in drug resistance. International journal of molecular sciences, 20(4), 857.

Tvrdík, D., Skálová, H., Dundr, P., Povýšil, C., Velenská, Z., Berková, A., Stanek, L., \& Petruželka, L. 2012. Apoptosisassociated genes and their role in predicting responses to neoadjuvant breast cancer treatment. Medical science monitor: international medical journal of experimental and clinical research, 18(1), BR60.

Vergara, F.P., Olivares-Corichi, I.M., PerezRuiz, A.G., Luna-Arias, J.P., \& GarcíaSánchez, J.R. 2020. Apoptosis induced by (-)-epicatechin in human breast cancer cells is mediated by reactive oxygen species. Molecules, 25(5), 1020.

Wang, Y., \& Zeng, S. 2018. Melatonin promotes ubiquitination of phosphorylated proapoptotic protein Bcl-2-interacting 
mediator of cell death-extra long (BimEL) in porcine granulosa cells. International journal of molecular sciences, 19(11), 3431.

Williams, M.M., \& Cook, R.S. 2015. Bcl-2 family proteins in breast development and cancer: could Mcl-1 targeting overcome therapeutic resistance?. Oncotarget, 6(6), 3519.

World Health Organization. 2020. Cancer Country Profiles 2020. https://www.who.int/cancer/countryprofiles/IDN_2020.pdf?ua=1
Xie, J., Xu, Y., Huang, X., Chen, Y., Fu, J., Xi, M., \& Wang, L. 2015. Berberineinduced apoptosis in human breast cancer cells is mediated by reactive oxygen species generation and mitochondrial-related apoptotic pathway. Tumor Biology, 36(2), 12791288.

Yan, W., Ma, X., Zhao, X., \& Zhang, S. 2018. Baicalein induces apoptosis and autophagy of breast cancer cells via inhibiting PI3K/AKT pathway in vivo and vitro. Drug design, development and therapy, 12, 3961.

(c) (i) (2) 